\title{
Blended Learning Approach in Arabic Teaching for Non-Native Speaker Students
}

\author{
$1^{\text {st }}$ Nuril Mufidah ${ }^{1}, 2^{\text {nd }}$ Saidna Zulfiqar Bin-Tahir ${ }^{2}, 3^{\text {rd }} M$. Irfan Islamy ${ }^{1}, 4^{\text {th }}$ Imam Rofiki $^{1}$ \\ \{nurilmufidah86@uin-malang.ac.id ${ }^{1}$, saidnazulfikar@gmail.com², irfan.islamy87@uin-malang.ac.id ${ }^{1}$ \} \\ Universitas Islam Negeri Maulana Malik Ibrahim Malang ${ }^{1}$ \\ Universitas Iqra Buru ${ }^{2}$
}

\begin{abstract}
The study attempted to measure the impact of the blended learning approach in Arabic teaching to the non-native speaker students of the Islamic state university in Indonesia. This research employed the quantitative method using the quasi-experimental design. There were 60 students participated in this study, which is divided into 30 students in each of the experimental, and control group. The data gained through the writing test have been analyzed by assisting the SPSS program. The results found that the students' score in the content got the highest score, and then followed by the grammar. It means that there were students who did not have the good score in Arabic writing through blended learning because only their writing content improved while their grammar did not improve significantly. Overall, the students' posttest score achievement in the experimental was higher than in the control group. Thus, it is crucial for further study to examine other skills of Arabic by using the blended learning approach.
\end{abstract}

Keywords: Arabic writing; blended learning; non-native speaker students

\section{Introduction}

In the digital era, the development of the information and communication technology (ICT) has become a necessity for all levels of society in all aspects of their life, as well as in education [1]-[5]. Therefore, it is possible to hold the distance learning by using the internet to connect between students and lecturers, checking the students' score online, finances, the schedule of college, sending assignments given by lecturers and so on.

It does not mean that the conventional learning is no longer entirely a mainstay, but in the midst of technological advances today, it takes a variety of methods that provide more opportunities to learn by utilizing various sources, not just from the manpower as well as educators [6], [7]. The learning required is to utilize information technology, leaving no direct guidance from the educator and the broader use of learning resources. This concept is also termed by mixing e-learning with the conventional so-called blended learning. Blended learning is an approach that combines the traditional or face-to-face learning with the online learning resources via the internet as the communication and interaction option in teaching and learning process [8]-[12].

The bended learning learning takes place more meaningfully because it utilizes various media and technology [13]. Students also do not just learn Arabic easily and casually, but there are interactions and social activities that enable them to apply their knowledge. Hence, 
the Arabic ability of the students is increasing, and the learning process motivates them to study diligently.

In the $21^{\text {st }}$ Century, educators should design and develop the learning material that assists students in acquiring the knowledge and skill such as the critical thinking, problem-solving, good communication and collaboration, and the creation and innovation value [14]-[16]. The innovative teaching methodology of Arabic Language amongst Non-Arabic speakers is suggested by integrating the technology in every single of education activity. The technology has become the crucial requirement in education to assist the success of teaching and learning process in improving the students' Arabic mastery and their communication skill [17][18][20].

In this study, the researchers applied a blended learning approach in teaching Arabic to measure the students' learning achievement in Arabic writing using the blended learning approach. The results of this study can be used for educators to design and develop the blended learning approach in Arabic teaching.

\section{Literature Review}

Zhao explains that blended learning is a new term that is difficult to define [21]. Although it is quite difficult to define the notion of blended learning, some experts who examine the blended learning mentions the concept of blended learning as an approach that integrates the traditional and face-to-face learning using online learning resources [22]-[25].

Al-hunaiyyan et al. stated that the blended learning, on the other hand, is merging the aspects of the e-learning such as the web-based instruction, video/audio, synchronous and asynchronous tools, etc., with the traditional or face-to-face learning methods [26]. Another identical definition proposed by Bicen who states that the concept of the blended learning is the newest model so-called blended e-learning (BEL). The BEL model is designed primarily based on the combination of online learning, structured face-to-face learning, and real-world practices [27]. Based on those definitions, it can be concluded that the blended learning is a combination of e-learning aspects regarding the web-based instruction, video streaming, audio, synchronous and asynchronous tools with the traditional face-to-face learning as well as the teaching methods, learning theories, and pedagogical components.

In teaching the Arabic writing, the researchers conducted six stages of the blended learning approach to optimize the results. The six stages include (1) specifying the kinds and materials of the teaching materials, (2) establishing the blended learning design, (3) setting the online learning format, (4) testing the design, (5) organizing the blended learning well, and (6) preparing the evaluation criteria of blended learning implementation. First, establish the kinds and materials of teaching materials. Researchers should be well aware of what relevant teaching materials are applied to distance education that is partly done in face-to-face learning and the online or web-based learning. Second, set the design of blended learning used. The design of learning should be well designed and involve e-learning experts to help. It is intended that the design of learning that is made relevant and facilitate the system of learning face to face and long distance, not even complicate students or other educational personnel in the provision of education. The blended learning design should consider (1) how the teaching materials are presented, (2) which teaching materials are mandatory to learn and which ones are recommended to enrich the knowledge, (3) how students can access the two components, 
(4) what support factors are needed, e.g., what software is used, whether it is necessary for group work or individuals only.

Third, set the format of online learning. Whether the teaching materials are available in PDF format, video, also need what the educator uses hosting notifications, whether Yahoo, Google, Facebook, or others. The recent study employed the combination of Facebook group wall discussion for the e-learning activities and face-to-face in the classroom interaction. Fourth, test the design made. This test is done to determine whether the learning system is running well or not. Starting from the effectiveness and efficient concerned, whether it makes it difficult for students and educators or even really facilitates learning. Fifth, organize blended learning well. Previously there has been socialization of teachers or lecturers about this system. They can start from the introduction of the task of each component of education and access teaching materials. Teachers or lecturers here served as promotional officers, because of the following the implementation of blended learning bias from parties themselves and even from other parties. Sixth, prepare criteria for evaluation. Examples of evaluations are: (1) easy to use, (2) the content, (3) layout and format, (4) interested, (5) applicable, and (6) cost consuming/value.

\section{Methods}

The study engaged the quasi-experimental design. This design employed two groups namely the experimental and control group. The experimental group has been treated using the blended learning approach and the control group by applying the conventional teaching and learning by presenting the Arabic writing material using drill technique [28].

The population of the research was the students of Arabic education department of Universitas Islam Negeri Maulana Malik Ibrahim Malang in academic year 2016/2017. The sample of this research was 60 students who divided into 30 students in the experimental group and 30 students in the control group. Both classes have been selected randomly. The class DK of the fourth semester was taken as an experimental group that implemented the blended learning approach, and the class $\mathrm{AK}$ was selected as a control group by considering that both students of the two groups have the same level and the same ability of Arabic writing.

The researchers employed the writing test to measure the students' learning achievement in two components of writing (Kitabah) such as the content and grammar through the tests. It consisted of the pretest before conducting the treatment and the posttest after holding the treatment. The pretest and posttest focused on the students' writing descriptive text.

Data on students' writing achievement have been scored using the writing rubric proposed by Heaton \& Coon [29] to be more focused on the content and grammar of writing scores and standard deviations using the SPSS version 17 program analysis. The data were presented descriptively and inferentially.

\section{Results and Discussion}

Based on the analysis, the researchers present the frequency and percentage of students' Arabic writing achievement in term of the content of writing scores of both the experimental and control group that can be seen in Table I. 
Table 1. The Frequency and Percentage of The Content Score Achievement in The Pretest

\begin{tabular}{clcccc}
\hline & & \multicolumn{2}{c}{$\begin{array}{c}\text { Experimental } \\
\text { Group }\end{array}$} & \multicolumn{2}{c}{$\begin{array}{c}\text { Control } \\
\text { Group }\end{array}$} \\
\hline $\begin{array}{c}\text { Range of } \\
\text { Score }\end{array}$ & $\begin{array}{c}\text { Classificatio } \\
\mathrm{n}\end{array}$ & $\mathrm{F}$ & $\%$ & $\mathrm{~F}$ & $\%$ \\
\hline $86-100$ & Excellent & 0 & 0 & 0 & 0 \\
$71-85$ & Very good & 0 & 0 & 0 & 0 \\
$56-70$ & Good & 2 & 6.7 & 1 & 3.3 \\
$41-55$ & Average & 5 & 16.6 & 3 & 10.0 \\
$26-40$ & Poor & 23 & 76.6 & 26 & 86.6 \\
$<25$ & Very Poor & 0 & 0 & 0 & 0 \\
\hline & Total & 30 & 100 & 30 & 100 \\
\hline
\end{tabular}

Table 1 presents that the students of both the experimental and control group pretest scores classified in the poor category. The percentage accumulation of the low achiever students in the pretest were 23 students $(76.6 \%)$ in the experimental group and 26 students $(86.6 \%)$ in the control group. The student's score classified in the good category were 2 students $(6.7 \%)$ in the experimental group and 1 student $(3.3 \%)$ in the control group. Based on those accumulations of the pretest scores, it indicated that the low achiever student's score was higher than the high achievers. It means that the students writing skill regarding the content of writing are still needed to be increased. After giving the treatment, the frequency and percentage of students' writing scores in term of the writing content in both groups has improved. It can be seen in Table 2.

Table 2. The Frequency and Percentage of The Content Score Achievement in The Posttest

\begin{tabular}{clcccc}
\hline & & \multicolumn{2}{c}{$\begin{array}{c}\text { Experiment } \\
\text { al Group }\end{array}$} & \multicolumn{2}{c}{$\begin{array}{c}\text { Control } \\
\text { Group }\end{array}$} \\
\hline $\begin{array}{c}\text { Range of } \\
\text { Score }\end{array}$ & Classification & F & $\%$ & F & $\%$ \\
\hline $86-100$ & Excellent & 0 & 0 & 0 & 0 \\
$71-85$ & Very good & 5 & 16.6 & 1 & 3.3 \\
$56-70$ & Good & 24 & 80.0 & 17 & 56.6 \\
$41-55$ & Average & 1 & 3.3 & 11 & 36.6 \\
$26-40$ & Poor & 0 & 0 & 1 & 3.3 \\
$<25$ & Very Poor & 0 & 0 & 0 & 0 \\
\hline & Total & 30 & 100 & 30 & 100 \\
\hline
\end{tabular}

Table 2 describes that the most students in the experimental group scores categorized in the high achievers in which 24 students $(80.0 \%)$ were in good category and 5 students $(16.6 \%)$ were in very good classification. The students' score in the control group also has improved after the treatment but not significantly as happened in the experimental group; there were 17 students $(56.6 \%)$ in good category and 1 student $(3.3 \%)$ in the very good category and 11 students $(36.6 \%)$ in the average classification.

The frequency and percentage scores of both the experimental and control group in term of grammar could be seen in Table 3 .

Table 3. The Frequency and Percentage of Grammar Score Achievement in The Pretest 


\begin{tabular}{clcccc}
\hline & & \multicolumn{2}{c}{$\begin{array}{c}\text { Experimental } \\
\text { Group }\end{array}$} & \multicolumn{2}{c}{$\begin{array}{c}\text { Control } \\
\text { Group }\end{array}$} \\
\hline $\begin{array}{c}\text { Range of } \\
\text { Score }\end{array}$ & $\begin{array}{c}\text { Classificatio } \\
\mathrm{n}\end{array}$ & $\mathrm{F}$ & $\%$ & $\mathrm{~F}$ & $\%$ \\
\hline $86-100$ & Excellent & 0 & 0 & 0 & 0 \\
$71-85$ & Very good & 0 & 0 & 0 & 0 \\
$56-70$ & Good & 2 & 6.7 & 1 & 3.3 \\
$41-55$ & Average & 8 & 26.7 & 7 & 23.3 \\
$26-40$ & Poor & 20 & 66.7 & 22 & 73.3 \\
$<25$ & Very Poor & 0 & 0 & 0 & 0 \\
\hline & Total & 30 & 100 & 30 & 100 \\
\hline
\end{tabular}

Table 3 describes that most of student's writing scores in both of the experimental and control groups in term of the grammar were still in the poor or low classification. There were 20 students $(66.6 \%)$ of the experimental group in the poor category and 2 students $(6.7 \%)$ in the good classification. While in the control group, there were 22 students $(73.3 \%)$ in the poor category and 1 student $(3.3 \%)$ in the good category. It illustrates that the low achiever students were higher than the very good achiever. It also indicates that the students writing skill in term of grammar should be increased.

The frequency and percentage of students writing scores in term of grammar after conducting the treatment can be illustrated in Table 4 .

Table 4. The Frequency and Percentage of Grammar Score Achievement in The Posttest

\begin{tabular}{clcccc}
\hline & & $\begin{array}{c}\text { Experiment } \\
\text { al Group }\end{array}$ & \multicolumn{2}{c}{$\begin{array}{c}\text { Control } \\
\text { Group }\end{array}$} \\
\hline $\begin{array}{c}\text { Range of } \\
\text { Score }\end{array}$ & Classification & F & $\%$ & F & $\%$ \\
\hline $86-100$ & Excellent & 0 & 0 & 0 & 0 \\
$71-85$ & Very good & 1 & 3.3 & 1 & 3.3 \\
$56-70$ & Good & 11 & 36.6 & 1 & 3.3 \\
$41-55$ & Average & 17 & 56.6 & 27 & 90.0 \\
$26-40$ & Poor & 1 & 3.3 & 1 & 3.3 \\
$<25$ & Very Poor & 0 & 0 & 0 & 0 \\
\hline & Total & 30 & 100 & 30 & 100 \\
\hline
\end{tabular}

Table 4 illustrates that most of the students' writing score after giving the treatment to both of experimental and control group were classified in the average category in which 17 students $(56.6 \%)$ of the experimental group were in the average classification and 11 students $(36.6 \%)$ were in the good category. The student's scores in the control group after the treatment were also in the average category. There were 27 students $(90 \%)$ in the average category, and 1 student $(3.3 \%)$ has a good classification. It means that there was no significant improvement in students writing skill regarding grammar. In the table below, the researchers presented the mean scores and standard deviation of both experimental and control group achievement in the pretest and posttest.

Table 5. The Mean Score And Standard Deviation Of Students' Writing Achievement In The Experimental And Control Group 


\begin{tabular}{ccccc}
\hline & Mean & $\mathrm{N}$ & $\begin{array}{c}\text { Std. } \\
\text { Deviation }\end{array}$ & $\begin{array}{c}\text { Std. } \\
\text { Error } \\
\text { Mean }\end{array}$ \\
\hline $\begin{array}{c}\text { Experimental } \\
\text { Pretest } \\
\text { Posttest }\end{array}$ & 39.80 & 30 & 10.56 & 3.18 \\
\hline $\begin{array}{c}\text { Control } \\
\text { Pretest } \\
\text { Posttest }\end{array}$ & 35.26 & 30 & 7.38 & 2.68 \\
\hline
\end{tabular}

The mean score and standard deviation were shown the difference scores in the pretest and posttest. The data obtained based on the computation analysis using SPSS version 17.0. The data presented in Table 5 illustrates that the mean scores of the pretest and posttest were different after conducting the treatment. It means that there was an improvement of students' writing skill in term of the content and grammar through the blended learning approach. It can be proved by the mean score gained in the posttest of the experimental group that is 70.20 , and the standard deviation was 6.50 . The mean score was high compared to the pretest score that is 39.80 with the standard deviation is 10.56 . Meanwhile, the mean score of the pretest in the control group was 35.26 with the standard deviation was 7.38 , and the mean score in the posttest was 51.10 with the standard deviation was 7.49. The mean scores in the pretest and posttest of both groups were different after giving the treatment $(70.20>39.80)$ and $51.10>35.26)$.

The hypotheses were tested using the inferential analysis. In this measuring, the researchers employed the t-test (testing of the significance) for the independent sample test, that is, a test aimed to know the significances of the differences between the result of the students' mean score in the pretest and posttest as can be presented in Table 6 .

Table 6. The Probability Value of T-Test In The Experimental and Control Group Scores Achievement

\begin{tabular}{ccccc}
\hline $\begin{array}{c}\text { Experimental } \\
\text { Group }\end{array}$ & $\mathrm{T}$ & $\begin{array}{c}\text { 2 Tailed } \\
\text { Value }\end{array}$ & $\alpha$ & Remarks \\
\hline $\begin{array}{c}\text { Pretest and } \\
\text { Posttest }\end{array}$ & $\begin{array}{c}25.89 \\
1\end{array}$ & 0.00 & 0.05 & $\begin{array}{c}\text { Significantly } \\
\text { Different }\end{array}$ \\
\hline Control Group & $\mathrm{T}$ & $\begin{array}{c}\text { 2 Tailed } \\
\text { Value }\end{array}$ & $\alpha$ & Remarks \\
\hline $\begin{array}{c}\text { Pretest and } \\
\text { Posttest }\end{array}$ & $\begin{array}{c}27.18 \\
2\end{array}$ & 0.00 & 0.05 & $\begin{array}{c}\text { Significantly } \\
\text { Different }\end{array}$ \\
\hline
\end{tabular}

The probability value of the t-test analysis of the experimental and control group scores presented in table 6 shows that there was a significant difference between the pretest and posttest scores. The gain of the probability value $(0.00)$ was smaller than the level of significance of the $t$-table used in this study $(0.05)$. It means that the probability value was small than the $\alpha$ value $(0.00<0.05)$. It indicated that the alternative hypotheses $\left(\mathrm{H}_{1}\right)$ was accepted and the null hypotheses $\left(\mathrm{H}_{0}\right)$ was rejected. Therefore, the researchers concluded that the data on posttest scores as the final results gave the significant difference and improvement. The use of the blended learning approach was able to give a greater contribution to the 
teaching of Arabic writing, especially improving the students' writing skill regarding the content and grammar.

The results showed that the use of the blended learning significantly improves the students writing skill. Specifically, the result of the mean score in the posttest. In the experimental group shows that the two aspects of writing such as content got the highest mean score followed by the grammar. The researchers assumed that the improvement of students' writing skill relating to the material presented in Facebook and the approach itself. The researchers assumed that during treatments, most of the students paid attention to the content and use them to construct an interpretation. Teaching and learning the language is to trigger student interest and motivation in the class. Besides, the researchers assumed that students were familiar with the topics. Meanwhile, the result of data analysis shows that the mean score of students' grammar is lower than content. The researchers assumed that grammar got the lowest mean score in posttest because students were not accustomed to focusing on the elements of grammar.

The effectiveness of the blended learning in teaching Arabic writing was supported by some previous findings [2], [19], [30]. Tamim [30] reported that the blended learning had positive impact to the students' empowerment. Sadik [19] asserted that the utilization of meaningful technology could improve students' achievement. Salikin \& Tahir's study reported that Yahoo Messenger and voice chat in language learning improved students' language skills where the students can expose their ideas freely with friends in the online learning, and they can establish their learning interaction joyfully [2].

The several types of the research findings on the use of blended learning in line with the advantages of online learning by Brown who stated that the online learning provided students' opportunity and their initiation in learning, face-to-face gave and taken, for practicing and negotiating the meanings, for extended conversational exchange, and for students rule adoption that otherwise be impossible [31]. Some advantages of blended learning could make students involve themselves directly in the process of teaching and learning [32]-[35]. It also can provide opportunities for all students to participate actively, particularly if the discussion is carried on in the blended learning approach. The researchers assumed that the advantages of blended learning had made students interested in learning and improved their Arabic writing skill.

\section{Conclusion}

The researcher comes to the following conclusions that the exploiting of the blended learning approach in teaching Arabic writing improved the students' writing skill in term of the content and grammar. The analysis results showed some students could not improve their Arabic writing through blended learning, because only their score of writing content improved but their grammar did not improve significantly. The experimental students' scores in the posttest are higher than the control group scores. Thus, the researchers recommend to the further research to investigate the use of the blended learning approach in Arabic teaching by considering the students' activeness controlling in e-learning, enhance their grammar, and consider the internet connection. 
Acknowledgements. This paper in conjuction with The 3rd International Conference on Islamic Education, Information Technology and Media: Challenges and Opportunities (ICIED) in Malang, East Java.

\section{References}

[1] M. S. Sahrir and N. A. Alias, "A study on Malaysian language learners' perception towards leraning Arabic via online games," GEMA Online J. Lang. Stud., vol. 11, no. 3, pp. 129-145, 2011.

[2] H. Salikin and S. Z. Bin-Tahir, "The social media-based approach in teaching writing at Jember university, Indonesia," Int. J. English Linguist., vol. 7, no. 3, pp. 46-57, 2017.

[3] R. Silverstone, "Introduction," in Media, technology and everyday life in Europe, Routledge, 2017, pp. 19-36.

[4] N. Selwyn, "The information aged: A qualitative study of older adults' use of information and communications technology," J. Aging Stud., vol. 18, no. 4, pp. 369-384, 2004.

[5] D. J. Leu, C. K. Kinzer, J. L. Coiro, and D. W. Cammack, "Toward a theory of new literacies emerging from the internet and other information and communication technologies," Theor. Model. Process. Read., vol. 5, no. 1, pp. 1570-1613, 2004.

[6] A. H. K. Yuen, N. Law, and K. C. Wong, "ICT implementation and school leadership: Case studies of ICT integration in teaching and learning," J. Educ. Adm., vol. 41, no. 2, pp. 158 $170,2003$.

[7] V. S. Cholin, "Study of the application of information technology for effective access to resources in Indian university libraries," Int. Inf. Libr. Rev., vol. 37, no. 3, pp. 189-197, 2005.

[8] D. R. Garrison and H. Kanuka, "Blended learning: Uncovering its transformative potential in higher education," internet High. Educ., vol. 7, no. 2, pp. 95-105, 2004.

[9] R. T. Osguthorpe and C. R. Graham, "Blended learning environments: Definitions and directions," Q. Rev. Distance Educ., vol. 4, no. 3, pp. 227-233, 2003.

[10] K. L. Dangwal, "Blended learning: An innovative approach," Univers. J. Educ. Res., vol. 5, no. 1, pp. 129-136, 2017.

[11] J. Poon, "Blended learning: An institutional approach for enhancing students' learning experiences," J. online Learn. Teach., vol. 9, no. 2, pp. 271-288, 2013.

[12] N. Hoic-Bozic, V. Mornar, and I. Boticki, "A blended learning approach to course design and implementation," IEEE Trans. Educ., vol. 52, no. 1, pp. 19-30, 2009.

[13] P. Shea and T. Bidjerano, "Learning presence: Towards a theory of self-efficacy, selfregulation, and the development of a communities of inquiry in online and blended learning environments," Comput. Educ., vol. 55, no. 4, pp. 1721-1731, 2010.

[14] A. T. Ottenbreit-Leftwich, K. D. Glazewski, T. J. Newby, and P. A. Ertmer, "Teacher value beliefs associated with using technology: Addressing professional and student needs," Comput. Educ., vol. 55, no. 3, pp. 1321-1335, 2010.

[15] R. L. DeHaan, "Teaching creativity and inventive problem solving in science," CBE-Life Sci. Educ., vol. 8, no. 3, pp. 172-181, 2009.

[16] G.-J. Hwang, C.-L. Lai, J.-C. Liang, H.-C. Chu, and C.-C. Tsai, “A long-term experiment to investigate the relationships between high school students' perceptions of mobile learning and peer interaction and higher-order thinking tendencies," Educ. Technol. Res. Dev., vol. 66, no. 1, pp. 75-93, 2018.

[17] S. Sirkemaa, "Implementing Information Technology in the Learning Process," 6th WSEAS 
Int. Conf. E-ACTIVITIES, Tenerife, Spain, December 14-16, pp. 263-267, 2007.

[18] S. Z. Bin-Tahir, "Multilingual teaching and learning at Pesantren Schools in Indonesia," Asian EFL J., vol. 98, pp. 74-94, 2017. 